\title{
Credit Constraint and Human Capital Investment: an empirical analysis using Brazilian Household Budget Survey ${ }^{1}$
}

\author{
Flávia Chein ${ }^{\dagger}$ and Cristine Pinto ${ }^{+}$
}

\begin{abstract}
This paper is a first step to understanding the relationship between credit market imperfections and inequality of opportunity in skill formation. The main goal is to identify the effects of the credit constraint on the optimal decision to human capital, in terms of degree of instruction, taking into account the household preferences for education. Our starting point is the theoretical model of Lochner \& Monge-Naranjo (2011). Following their model, we propose a reduced form approach that estimates the relation between education decision and initial wealth in Brazil. This empirical analysis is conducted using data from a Brazilian Household Budget Survey (POF), for years 20022003 and 2008-2009. Our results point out that education decision is in fact credit constrained. The empirical estimates show a strong and highly significant effect of wealth on educational level of children, teenagers and adults, even controlling by education expenditures. On average, the initial wealth was responsible for an increase of more than 5 years of schooling. But we find no evidence of credit constraint on high level education decision, like undergraduate and graduate levels.
\end{abstract}

\section{Resumo}

Este artigo é um primeiro passo para entender a relação entre imperfeições do mercado de crédito e desigualdade de oportunidades na formação de habilidades.O objetivo principal é identificar os efeitos da restrição de crédito sobre a decisão ótima de investimento em capital humano, em termos de grau de instrução, controlando pelas preferências pela educação do domicílio. O ponto de partida é o modelo teórico de Lochner \& Monge-Naranjo (2011). Seguindo seu modelo, propõe-se uma abordagem na forma reduzida para estimar a relação entre a decisão de educação e riqueza inicial no Brasil. Esta análise empírica é realizada utilizando dados das Pesquisas de Orçamento Familiar do Brasil (POF), para os anos 2002-2003 e 2008-2009. Os resultados encontrados indicam que a decisão sobre investimento em educação enfrenta, de fato, restrições de crédito. As estimativas empíricas mostram um efeito forte e altamente significativo da riqueza sobre o nível educacional de crianças, adolescentes e adultos, mesmo controlando por gastos com educação. Em média, a riqueza inicial é responsável por um aumento de mais de 5 anos de escolaridade. Entretanto, não há nenhuma evidência de restrição de crédito sobre a decisão de investimento em ensino superior ou pós-graduação.

JEL Classification: C5, I25, D3, DI

Key Words: Wealth, credit constraint, human capital, educational attainment Palavras Chave: Riqueza, restrição de crédito, capital humano, anos de estudo Area: 12 - Economia Social e Demografia Econômica

\footnotetext{
${ }^{1}$ This project received funds from Swiss Program for Research on Global Issues for Development (r4d program) under the thematic research module "Employment in the context of sustainable development" and the research project "Trade and Labor Market Outcomes in Developing Countries". We are also thankful to CNPq and FAPEMIG for financial support.

$\dagger$ Department of Economics, Federal University of Juiz de Fora; Research Productivity Fellow (CNPq National Research Council);E-MAIL: flavia.chein@ufjf.edu.br; ffchein@gmail.com

+ São Paulo School of Economics - EESP/ FGV; Research Productivity Fellow (CNPq National Research Council); E-MAIL: cristine.pinto@fgv.br.
} 


\section{Introduction}

Historically, poverty has been a persistent phenomenon, a process whose change is very slow. The characteristics of poverty often generate determinants based on "sticky" variables or indicators that is resistant to change, such as resource allocation and geographic factors (location, climate, soil quality). However, the fact that there have been significant shifts in the levels of poverty in some countries or regions, makes explanations necessary for such changes (Lipton \& Ravaillion, 1995; Besley \& Burgess, 1998).

In this sense, poverty can be seen, for example, as a result of the market failures (Banerjee \& Newman , 1993), as arising from the institutions, the way societies are organized (Acemoglu et al., 2002), or merely as a result of the initial allocations of natural resources, climate, soil characteristics, and other geographical determinants (Gallup et al.,1999).

From the point of view of individual behavior and family decisions, the economic literature has stressed that the credit market imperfections is one of the necessary ingredients to the occurrence of the poverty trap - the fact that families are poor for being poor in prior periods or having originated from other poor families. The lack of resources needed to finance the investment limits the ability of families to escape from poverty (Galor \& Zeira , 1993; Banerjee \& Newman, 1993; Ghatak \& Jiang, 2002). On an aggregate perspective, the disability creates an inefficiency, since the poor can not get out of their condition of poverty not because they are less productive or lacking the necessary qualifications, but simply because market imperfections restrains the full realization of their potential (Deininger, 1999).

Family decisions concerning education, health and fertility are intrinsically related. Poor families typically have many children and invest little in education and health of children. These characteristics of poor families reduce the likelihood that they come out of poverty when they reach adulthood. This perverse interaction results in the reproduction of poverty and inequality across generations. One of its fundamental cause is the inability of poor families to ensure a minimally satisfactory level of consumption and, at the same time, sufficient income to keep children in school and to invest adequately in family health. This problem is particularly intensified by the lack of access to credit by poor households. Without access to credit, investments in health and education of children are not happening even when, from a purely financial perspective, they would be profitable (or better, the impact of investments in health and education on the future income of the child would be more than sufficient to pay the investments). In this context, if the family had access to credit, she may decide to have fewer children and invest more in education and health of each child, which would open the possibility that the next generation escape poverty.

Based on this context, the present work focuses on identifying the effects of the credit constraint on the optimal decision to human capital, in terms of degree of instruction, taking into account the household preferences for education. Its is just a first step in order to understanding the relationship between imperfections in credit market and inequality of opportunity in skill formation.

Our results point out that education decision is in fact credit constrained. The empirical estimates show a strong and highly significant effect of wealth on educational level of children, teenagers and adults, even controlling by education expenditures. The remainder of the paper is organized as follow. Section 2 presents a brief review of imperfections in the credit market and their effect on individual decisions, specially those related to education. Section 3 brings the theoretical model. Section 4 is concerned about data base and empirical strategy. Section 5 discusses the results and, finally, section 6 reports the main conclusions and make the final comments. 


\section{Literature Review}

The imperfections in the credit market are usual associated with asymmetric information. Jaffe \& Russel (1976) explain the constraints in the credit market using the basic ideas of moral hazard and adverse selection. They build a model in which there are two types of borrowers, honest and dishonest. Honest borrowers accept only loan contracts and they can pay; and dishonest borrowers default if the cost of default is low. The lenders know that there are two types of borrowers in the market, but they do not have any prior information about the type of a borrower. If they lend a great amount of money or increase the interest rate, they can attract only the dishonest borrowers. With the purpose of avoiding adverse selection, they decrease the interest rate and limited the amount of credit in the market. Stiglitz \& Weiss (1981) use the same principles to explain credit constraints. These authors show how the incentives in the market can affect not only the type of potential borrowers (adverse selection), but also the behavior of the borrowers in the market (moral hazard). One of the drawbacks of these studies is that they explain adverse selection and moral hazard problems in the credit market using only changes in the interest rate. This approach is too simple since the credit markets are regulated by specific institutions and other mechanisms used in this market, like collateral, can be related to adverse selection and moral hazard.

Stiglitz \& Weiss (1981) and Bell (1988) study how the collateral is related to the design of the contracts in the credit market. If borrowers can offer a collateral that exceeds the principal, there is full guarantee and no credit constraints. However, if the lenders request high value collateral, the contract may attract only the borrowers that are willing to invest in high risk project with a higher return. Even in the presence of the collateral, credit constraints can exist.

In this research, we relate credit constraint with the risk of a contract default. The household with low wealth that do not have the initial capital to start a new project need to borrow money in the credit market. Given the asymmetric information in the credit market, the lenders will requires some loan guarantees, like a collateral. The low wealth individuals could not provide these guarantees and have access to a limited amount of credit, as a consequence they cannot invest in projects that have higher returns.

Another side of literature assume that there are credit constraints and study the impact of these constraints on investment, and how these constraints can explain the income inequality and poverty in some countries. Banerjee \& Newman (1991) and Banerjee \& Newman (1993) relate credit constraints with income inequality. In the first paper, the authors understand credit constraints as a consequence of financial contract incentives. The insurance of a high risk contract with higher return is not possible because of "moral hazard", and the low-income households have limited access to credit, and cannot invest in human capital or projects with higher return. This limited access to credit is related with the persistence of income inequality. In the other paper, Banerjee \& Newman relate credit constraints with occupational choice and income inequality. Aghion \& Bolton (1997) study credit constraints in a moral hazard framework like in Banerjee \& Newman (1991). In their model, the level of effort of an individual in a project is a decreasing function of the size of the loan. The agents are risk neutral, and they face a limited amount of credit in the market. These four studies understand the imperfections in the credit market as an asymmetric information problem. These imperfections can be of two types: limited credit for certain individuals or a higher risk premium applied to the amount borrowed. In this market, the low income individuals could not provide the guarantees requested to obtain the initial capital to start a high return project, and consequently, they invest in projects with low return. Limited access to credit is one of the mechanism that can be used to explain the persistence of income inequality.

Other papers investigate how credit constraints are related to the productivity of certain groups using household surveys or data about small businesses. Rosenweig \& Wolpin (1993) analyze how the small land owners in India are affected by credit constraints. They develop a dynamic model in which the investment decisions are related to main characteristics of the small rural owners in 
India: small income and limited credit. The results of this model indicate low productivity and low profit are consequences of risk averse individual with low wealth and limited credit, and that credit constraints also increase the income volatility of these individuals.

Using a different approach, Kochar (1995) also investigates credit constraints in the rural market in India. The author investigates if the rural households in India face constraints that are related to the formal rules that regulates the access to formal credit. He considers that there are two credit markets in India: a formal one and an informal market. The demand for formal credit can be low not only because of the rules that limited the participation of the rural population in this market, but also because the informal credit is a good substitute for the formal credit, and in the informal market the cost of transactions are lower than in the formal one. Another study about the credit market in rural India is Jacoby \& Skoufias (1997). This study focuses on the relationship between the credit constraints and the accumulation of human capital. They investigate if credit constraints are related to child labor in India. If low income households have limited access to the formal and informal credit market, when the household income is very low, children in the rural households in India have to work to help at home. The consequences of child labor in India is low educational level, less accumulation of human capital and low productivity in the region. Towsend (2002) analyzes the credit market in Thailand. Using a household survey, the author provides evidence that there are credit constraints, and relates these constraints with income inequality and poverty. Ardagna \& Lusardi (2008) use micro data that has information of individuals in different countries to estimate the determinants of entrepreneurship. They find that one of the main determinants are regulation, measure by the barriers and costs entrepreneurs face to open a new business, the efficiency of the justice system in resolving commercial disputes, and others.

There are still few studies that examine the direct relationship between asymmetric in credit and investment in human capital market. Carneiro \& Heckman (2002) identify the short-term effects and long-term effects of credit constraints on the probability of entering university. The long term effects are related to the fact that low income families can not invest in their children's education from early childhood education, leading to a non-development of non-cognitive abilities of the same. This lack of noncognitive skills as well as the lack of resources for university entrance decrease the likelihood of students in these poor families to get an undergraduate degree. The authors show evidence that the effects of long-term credit constraints are stronger than the short-term effects. Mimoun (2008) estimates the effect of credit constraints in enrollment in higher education, using a database that contains information on various countries. He presents evidence that credit market restrictions negatively affect investment in human capital. Cameron \& Tabel (2004) show evidence that the restrictions in the credit market do not generate large inefficiencies in the educational market and partnerships to improve access to the credit market in the United States public policy would not have had a significant effect on the education acquired by the Americans.

In Brazil, the number of papers on the credit market and its relation to individual decisions is still quite restricted. Based on the Brazilian Household National Survey (PNAD) for the years 1981 to 2001, Assunção \& Alves (2007) present empirical evidence that the restrictions in the credit market has impact on intra-household decisions, like investment in education and child labor. Assunção \& Chein (2007) analyze the credit conditions of families living in rural areas in Brazil. The authors suggest strong evidence of credit rationing in these areas. In the same line, Madeira et al. (2010) analyze the effects of recent changes in the Brazilian legal system that worked to minimize credit enforcement's reliance on sluggish courts and the assorted risks and costs associated with litigations. Their results suggest robust effects of the new credit instrument in two kind of decisions: i) on the probability of engagement on entrepreneurial activities both by pensioners and their family members, and; ii) ownership of durable consumption goods.

Given the importance of credit market and human capital on development, in this article we investigate if credit constraint has an effect on optimal decision to education investment. 


\section{Theoretical Model}

In this section, we present a very simple model that motivates our empirical strategy. Based on Lochner \& Monge-Naranjo (2011), we propose a simple model in which individuals live only two periods. In the first period, they invest in schooling; and in the second period, they work. Their preferences depend on consumption in both periods and is represented by

$$
U=u\left(c_{0}\right)+\beta u\left(c_{1}\right)
$$

where $c_{t}$ is consumption on period $t$, and $\beta>0$. The function $u($.$) is strictly concave and increasing.$

In period 1, each individual can choose three schooling levels: elementary school, high school or college. In our model, the school level is represented by $h, h \in\{0,1,2\}$. Individual starts life with an initial wealth $W \geq 0$ and certain level of ability $a \geq 0$. In our model, initial wealth represents family transfers and ability captures childhood investments. We follow Lochner and Monge-Naranjo (2011) and take $(W, a)$ as given.

The income level of each individual in period $1(y)$ depends on the level of school that he/she chooses in period $0(h)$,

$$
y=w_{h} \cdot a \cdot f(h)
$$

where $f($.$) is positive, strictly increasing and concave, w_{h}$ is the price of human capital. We assume that the price of education is increasing in its level.

In addition, each unit of human capital has a financial cost denoted by $\tau$. The marginal and total return of investment in human capital increases with ability. Individual can borrow $d$ at a gross interest rate $R>0$. There is a cap in the amount of debt that the individual can accumulate, $d \leq \bar{d}$, where $0 \leq \bar{d} \leq \infty$.

In period 0 , individual's consumption will depend on initial wealth, the cost of the human capital and the amount borrowed,

$$
c_{0}=W-\tau h+d
$$

In period 1, individual's consumption is given by,

$$
c_{1}=w_{h} a f(h)-R d
$$

Individuals choose $h, d$ to maximize his utility subject to the three constraints,

$$
\max _{(h, d)} u\left(c_{0}\right)+\beta u\left(c_{1}\right)
$$

subject to

$$
\begin{gathered}
d \leq \bar{d} \\
c_{0}=W-\tau h+d \\
c_{1}=w_{h} a f(h)-R d
\end{gathered}
$$

The first order conditions of this problem are:

$$
\begin{gathered}
h: u^{\prime}(W-\tau h+d)(-\tau)+\beta u^{\prime}\left(w_{h} a f(h)-R d\right) w_{h} a f^{\prime}(h)=0 \\
d: u^{\prime}(W-\tau h+d)+\beta u^{\prime}\left(w_{h} a f(h)-R d\right)(-R)-\lambda_{1}=0
\end{gathered}
$$

If the credit constraint is binding,

$$
d^{*}(W, a)=\bar{d}
$$


and the optimal level of human capital is given by

$$
\frac{w_{h} a f^{\prime}\left(h^{*}\right)}{\tau}=R+\frac{\lambda_{1}}{\beta u^{\prime}\left(w_{h} a f\left(h^{*}\right)-R d^{*}\right)}
$$

In this case, there is a level of wealth that determines who is constrained, $W_{\min }(a)$. If $W<$ $W_{\min }(a)$, the individual is constrained. The optimal level of schooling is implicit determined by:

$$
u^{\prime}\left(W-\tau h^{*}+d\right)(\varpi+\tau)=\beta u^{\prime}\left(w_{h^{*}} a f\left(h^{*}\right)-R d\right) w_{h^{*}} a f^{\prime}\left(h^{*}\right)
$$

When the constraint is binding, the optimal amount of human capital investment is strictly increasing on initial wealth and borrowing limit $\bar{d}$. Constrained individuals underinvest in human capital.

If the credit constraint is not binding, the optimal level of human capital is given by

$$
\frac{w_{h} a f^{\prime}\left(h^{*}\right)}{\tau}=R
$$

In this case, the schooling level does not depend on the initial wealth.

\section{Database and Empirical Strategy}

According to the IBGE (2006), Household Budget Surveys ("Pesquisa de Orçamentos Familiares - $\left.P O F^{\prime \prime}\right)$ are intended to measure, based on representative samples of the target population, the structure of consumption, spending and household income. Thus, it is possible, from the POF, assess living conditions based on budgets. In addition to information regarding the budget framework, a diversity of the household and families characteristics are investigated, expanding the potential use of the research results. It is therefore possible to study the composition of household spending by classes of income and regional disparities, urban areas among themselves and between urban and rural areas, the role and extent of household debt, the spread and volume of transfers between different classes of income and the size of the consumer market for product groups and services.

The POF provides information broken down into four separate questionnaires: the household, collectively spending, personal spending and income. In the questionnaires of households, data on the characteristics of households and their residents are presented. Among this information, there are the living conditions and personal characteristics such as age and education level. In income and expenditures questionnaires there are detailed information about the main occupations and incomes of individuals, as well as data referring to different types of expenditures made by households, for example, expenditures on food, entertainment, transport, culture and education. The units of analysis of POF are individuals and consumption units.

The choice of POF as our data source relies on the fact that it is a database still not explored to evaluate issues related to credit rationing and investment in human capital. Most of the national literature investigates the issue using information collected by the Census and the National Household Survey (PNAD). Thus, the use of POF becomes important as it adds new evidence to credit constraint in Brazil. In this paper we use data from the two most recent surveys, that is, the POF from years 2002-2003 and from 2008-2009.

The first step of our empirical strategy is the definition of the wealth variable that we are going to use here. Our wealth variable is a index composed of 21 variables concerning living conditions and access to durable goods. This index is constructed using principal component analysis as reported in Table 1 and was normalized to vary between 0 and 1. All variables referring to durable goods is measured as the total number of each kind of good, considering the inventory and purchases. 


\begin{tabular}{lcc}
\hline Variables & $\mathbf{2 0 0 2 - 2 0 0 3}$ & $\mathbf{2 0 0 8 - 2 0 0 9}$ \\
\hline Air conditioning & 0.2091 & 0.2222 \\
Stoves & 0.1307 & 0.1166 \\
Freezers & 0.2215 & 0.1844 \\
Refrigerators & 0.2172 & 0.1971 \\
Cars & 0.2933 & 0.3131 \\
TV & 0.3235 & 0.3229 \\
Computer & 0.2733 & 0.3183 \\
Dishwasher & 0.2056 & 0.1643 \\
Washing machine & 0.2592 & 0.2735 \\
Drying machine & 0.1701 & 0.1334 \\
Microwave & 0.2768 & 0.2858 \\
Number of residents & -0.0432 & -0.0212 \\
Number of rooms & 0.2982 & 0.3185 \\
Number of bedrooms & 0.1366 & 0.1479 \\
Number of bathrooms & 0.3354 & 0.3458 \\
Paving & 0.2054 & 0.2048 \\
Own domicile & 0.0572 & 0.0688 \\
Sewage & 0.1980 & 0.1946 \\
Water supply system & 0.1670 & 0.1535 \\
House of flat & 0.1217 & 0.0432 \\
Suitable floor & 0.1151 & 0.0770 \\
\hline Number of Observations & 181733 & 181733 \\
Variance Explained & $25.31 \%$ & $23.13 \%$ \\
\hline Source: Authors' Elaboration based on POF 2002-2003 e 2008-2009(IBGE)
\end{tabular}

Table 1: Principal Component Analysis - Wealth Index

The distribution of wealth index for years 2002-2003 and 2008-2009 are depicted, respectively, on Graph 1 and Graph 2. We observe a concentration of individuals on the lower tail of the distribution, which level of wealth is below 0.5. We observe the same pattern in 2002-2003 and 2008-2009 surveys.

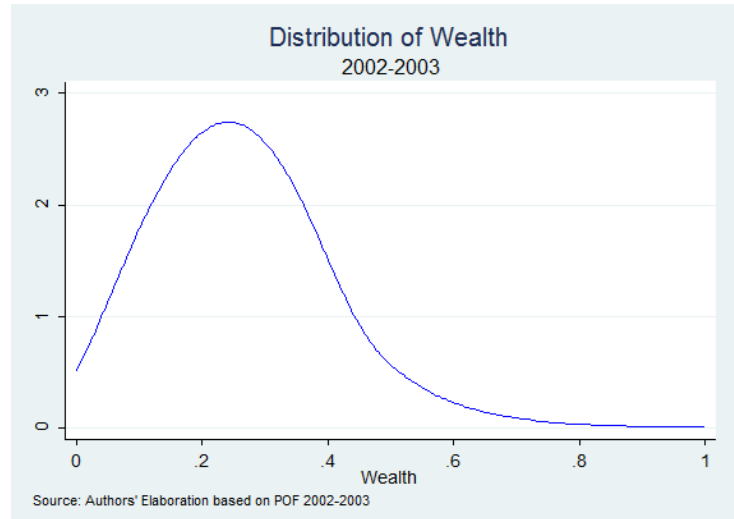

Graph 1: Distribution of Wealth 2002-2003

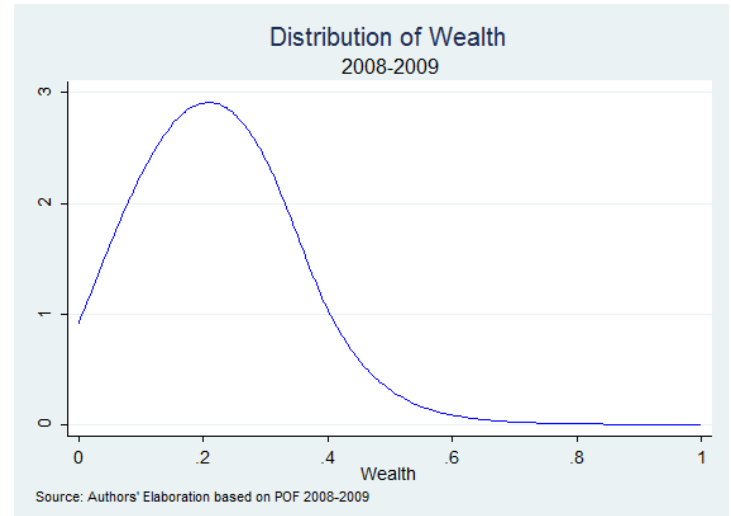

Graph 2: Distribution of Wealth 2008-2009

Table 2 shows a quickly descriptive analysis of our main variable considering those above and below the median of wealth. It is worth mentioning that, in generally, those above wealth median have higher level of education and educational expenditures. All the differences between the two groups of wealth are highly significant. 


\begin{tabular}{|c|c|c|c|c|c|c|c|c|c|c|c|c|}
\hline \multirow[b]{2}{*}{ Variables } & \multicolumn{6}{|c|}{ 2002-2003 } & \multicolumn{6}{|c|}{ 2008-2009 } \\
\hline & Below Median & Above Median & Difference & t-stat & & Observations & Below Median & Above Median & Difference & t-stat & & Observations \\
\hline Wealth & $\begin{array}{c}0.170 \\
(0.000199)\end{array}$ & $\begin{array}{c}0.318 \\
(0.000610)\end{array}$ & 0.149 & 232.0 & $* * *$ & 181,733 & $\begin{array}{c}0.156 \\
(0.000136)\end{array}$ & $\begin{array}{c}0.278 \\
(0.000419)\end{array}$ & 0.122 & 276.6 & $* * *$ & 188,346 \\
\hline Household Income & $\begin{array}{c}706.6 \\
(4.028)\end{array}$ & $\begin{array}{c}2,610 \\
(20.59)\end{array}$ & 1.903 & 90.71 & $* * *$ & 188,346 & $\begin{array}{c}1,145 \\
(4.604)\end{array}$ & $\begin{array}{c}3,977 \\
(26.16)\end{array}$ & 2.833 & 106.7 & *** & 188,346 \\
\hline Preschool Level & $\begin{array}{c}0.0438 \\
(0.000987)\end{array}$ & $\begin{array}{c}0.0343 \\
(0.00102)\end{array}$ & -0.00949 & -6.683 & $* * *$ & 188,346 & $\begin{array}{c}0.305 \\
(0.00224)\end{array}$ & $\begin{array}{c}0.205 \\
(0.00198)\end{array}$ & -0.100 & -33.51 & $* * *$ & 188,346 \\
\hline Elementary Level & $\begin{array}{c}0.0521 \\
(0.00130)\end{array}$ & $\begin{array}{c}0.0878 \\
(0.00169)\end{array}$ & 0.0357 & 16.73 & $* * *$ & 188,346 & $\begin{array}{c}0.124 \\
(0.00168)\end{array}$ & $\begin{array}{c}0.152 \\
(0.00180)\end{array}$ & 0.0279 & 11.35 & $* * *$ & 188,346 \\
\hline High School Level & $\begin{array}{c}0.0481 \\
(0.00121)\end{array}$ & $\begin{array}{c}0.200 \\
(0.00236)\end{array}$ & 0.152 & 57.27 & $* * *$ & 188,346 & $\begin{array}{c}0.102 \\
(0.00153)\end{array}$ & $\begin{array}{c}0.264 \\
(0.00227)\end{array}$ & 0.162 & 59.26 & $* * *$ & 188,346 \\
\hline Undergraduate Level & $\begin{array}{c}0.00142 \\
(0.000210)\end{array}$ & $\begin{array}{c}0.0468 \\
(0.00132)\end{array}$ & 0.0453 & 33.87 & $* * *$ & 188,346 & $\begin{array}{c}0.00594 \\
(0.000372)\end{array}$ & $\begin{array}{c}0.0851 \\
(0.00159)\end{array}$ & 0.0791 & 48.58 & *** & 188,346 \\
\hline Graduate Level & $\begin{array}{c}0.000312 \\
(6.52 \mathrm{e}-05)\end{array}$ & $\begin{array}{c}0.0118 \\
(0.000623)\end{array}$ & 0.0115 & 18.39 & $* * *$ & 188,346 & $\begin{array}{c}0.000698 \\
(0.000116)\end{array}$ & $\begin{array}{c}0.019 \\
(0.000740)\end{array}$ & 0.0183 & 24.37 & $* * *$ & 188,346 \\
\hline Total Expenditures & $\begin{array}{c}3,089 \\
(18.59)\end{array}$ & $\begin{array}{l}13,599 \\
(127.4)\end{array}$ & 10.510 & 81.63 & $* * *$ & 187,455 & $\begin{array}{c}1,323 \\
(29.89)\end{array}$ & $\begin{array}{c}7,776 \\
(230.2)\end{array}$ & 6.452 & 27.79 & $* * *$ & 187,455 \\
\hline Educational Expenditures & $\begin{array}{c}2,313 \\
(13.82)\end{array}$ & $\begin{array}{c}9,944 \\
(77.91)\end{array}$ & 7.632 & 96.45 & $* * *$ & 187,455 & $\begin{array}{c}1,202 \\
(18.83)\end{array}$ & $\begin{array}{c}6,595 \\
(76.41)\end{array}$ & 5.392 & 68.52 & $* * *$ & 187,455 \\
\hline Preschool Expenditures & $\begin{array}{c}511.2 \\
(4.809)\end{array}$ & $\begin{array}{c}1,312 \\
(15.00)\end{array}$ & 801.0 & 50.85 & $* * *$ & 187,455 & $\begin{array}{c}155.1 \\
(14.40)\end{array}$ & $\begin{array}{c}1,155 \\
(47.41)\end{array}$ & 999.5 & 20.17 & $* * *$ & 187,455 \\
\hline Elementary Expenditures & $\begin{array}{c}341.5 \\
(4.956)\end{array}$ & $\begin{array}{c}941.4 \\
(11.61)\end{array}$ & 600.0 & 47.51 & $* * *$ & 187,455 & $\begin{array}{c}87.98 \\
(0.967)\end{array}$ & $\begin{array}{c}609.7 \\
(15.78)\end{array}$ & 521.7 & 32.99 & $* * *$ & 187,455 \\
\hline High School Expenditures & $\begin{array}{c}230.4 \\
(2.408)\end{array}$ & $\begin{array}{c}825.9 \\
(9.205)\end{array}$ & 595.5 & 62.58 & $* * *$ & 187,455 & $\begin{array}{c}117.0 \\
(1.774)\end{array}$ & $\begin{array}{c}508.6 \\
(6.593)\end{array}$ & 391.6 & 57.36 & $* * *$ & 187,455 \\
\hline Undergraduate Expenditures & $\begin{array}{c}87.69 \\
(2.715)\end{array}$ & $\begin{array}{c}855.6 \\
(16.47)\end{array}$ & 767.9 & 46.00 & $* * *$ & 187,455 & $\begin{array}{c}250.6 \\
(3.276)\end{array}$ & $\begin{array}{c}1,229 \\
(25.43)\end{array}$ & 978.2 & 38.15 & $* * *$ & 187,455 \\
\hline Graduate Expenditures & $\begin{array}{c}72.12 \\
(1.604)\end{array}$ & $\begin{array}{c}291.3 \\
(6.426)\end{array}$ & 219.2 & 33.10 & $* * *$ & 187,455 & $\begin{array}{c}21.21 \\
(0.628)\end{array}$ & $\begin{array}{c}128.2 \\
(4.797)\end{array}$ & 107.0 & 22.12 & $* * *$ & 187,455 \\
\hline Fees & $\begin{array}{c}121.8 \\
(1.851)\end{array}$ & $\begin{array}{c}669.9 \\
(18.58)\end{array}$ & 548.1 & 29.35 & $* * *$ & 187,455 & $\begin{array}{c}84.52 \\
(2.959)\end{array}$ & $\begin{array}{c}377.5 \\
(6.387)\end{array}$ & 293.0 & 41.62 & *** & 187,455 \\
\hline Books & $\begin{array}{c}214.2 \\
(3.093)\end{array}$ & $\begin{array}{c}1,412 \\
(14.68)\end{array}$ & 1.197 & 79.80 & $* * *$ & 187,455 & $\begin{array}{c}47.43 \\
(0.893)\end{array}$ & $\begin{array}{c}305.4 \\
(5.466)\end{array}$ & 257.9 & 46.57 & $* * *$ & 187,455 \\
\hline Other Educational Expenditures & $\begin{array}{c}733.7 \\
(5.133)\end{array}$ & $\begin{array}{c}3,636 \\
(30.96)\end{array}$ & 2.903 & 92.49 & $* * *$ & 187,455 & $\begin{array}{c}438.4 \\
(5.796)\end{array}$ & $\begin{array}{c}2,282 \\
(28.37)\end{array}$ & 1.843 & 63.68 & $* * *$ & 187,455 \\
\hline
\end{tabular}

Source: Authors' Elaboration based on POF 2002-2003 e 2008-2009 (IBGE)

Standard errors in parentheses

${ }^{* * *} p<0.01,{ }^{* *} p<0.05,{ }^{*} p<0.1$

Table 2: Descriptive Statistics

The graphical analysis of the relation between wealth and education investments are presented in Graph 3 to Graph 6. A quick view on theses graphs points that human capital investment and education investment increases according to decile of wealth. This is a first evidence in favour of initial assumption of credit constraint in human capital decision.

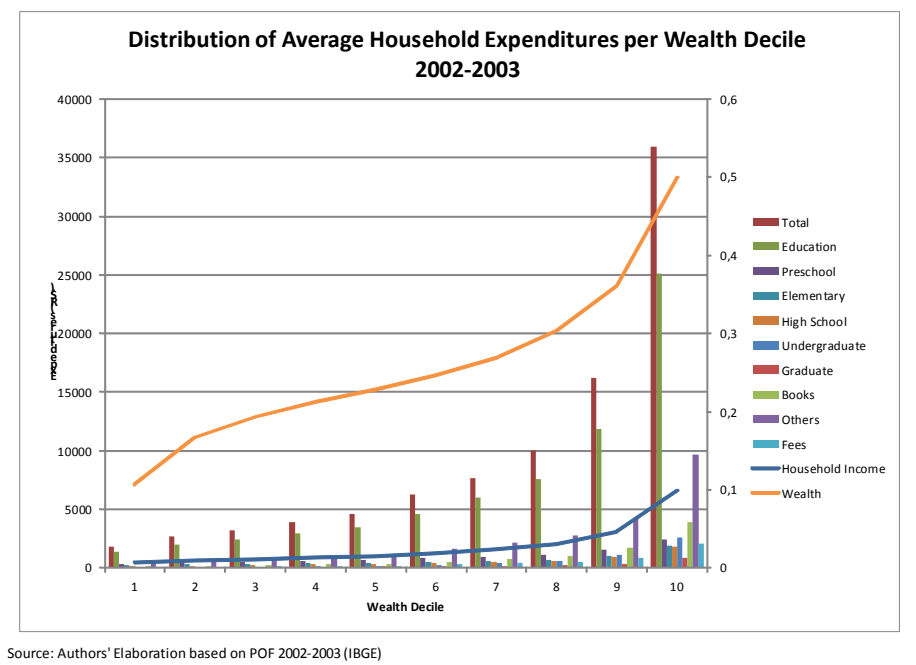

Graph 3: Distribution of Average Expenditures per Wealth Decile 2002-2003 


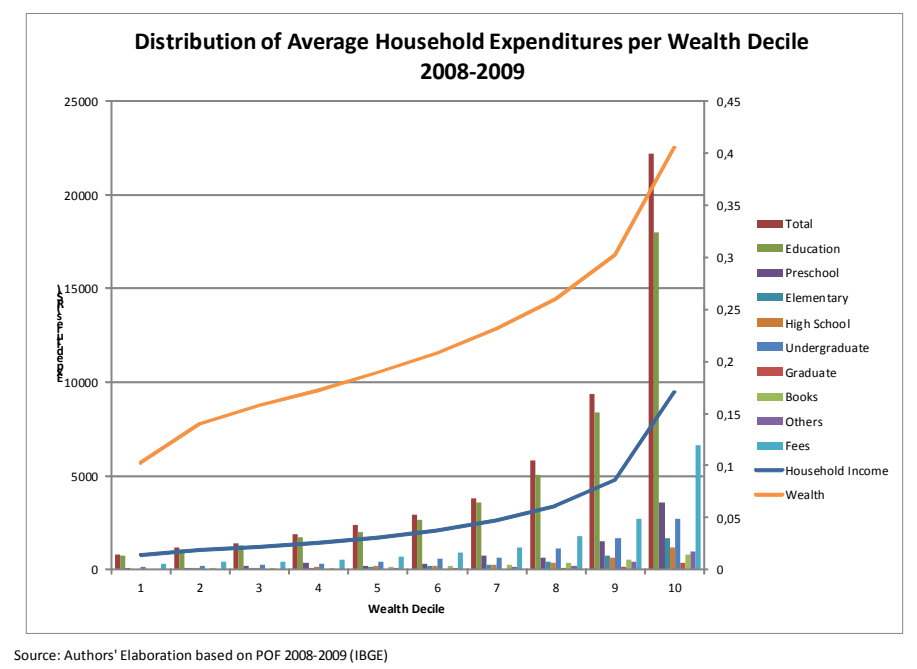

Graph 4: Distribution of Average Household Expenditures per Wealth - 2008-2009

While Graph 3 and Graph 4 bring us information about spendings on education, revealing that preference for education seems to increase with wealth, Graph 5 and Graph 6 show a clearly increase in average human capital stock as we move from the lowest decile of wealth to highest one. It is worth noting that graphs are based on school level attendance considering the last grade conclude and the specifics ages for each level of school attendance ${ }^{2}$.

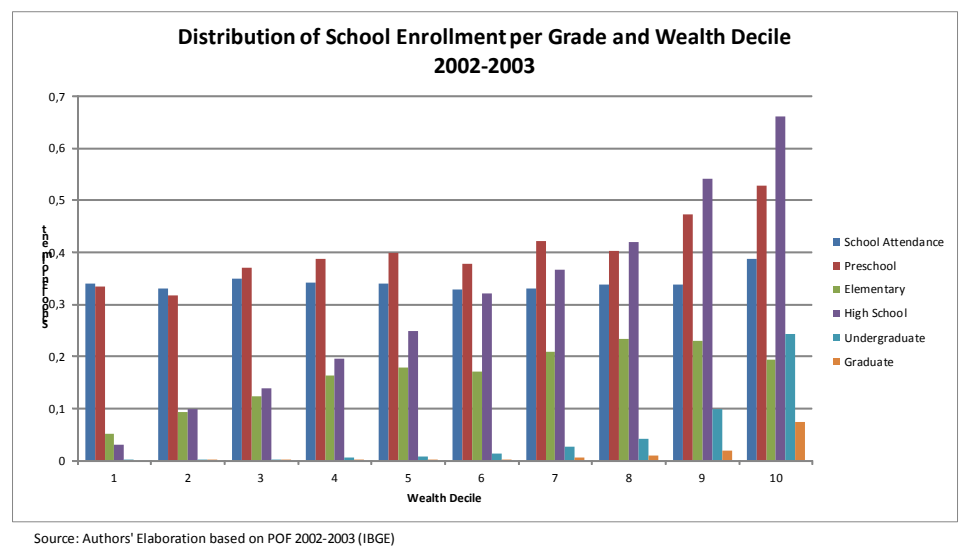

Graph 5: Distribution of School Enrollment per Grade and Wealth Decile 2002-2003

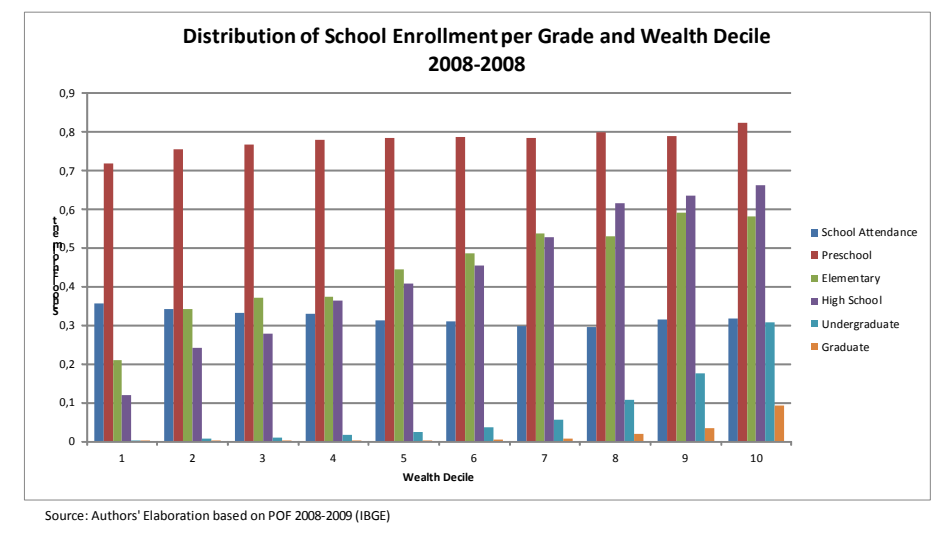

Graph 6: Distribution of School Enrollment per Grade and Wealth Decile 2008-2009

\footnotetext{
${ }^{2}$ For preschool we considered children aged 4-7 years old; for elementary level we taking into account only students aged 14-18, in the case of high school, we include studentes aged 17 to 25 . For undergraduate we considered studantes aged 21 or more. Finally, in graduation all students aged 23 or more was included.
} 
Just to complement the analysis above, Graphs 7 and 8 depict the smoothed relation between years of schooling and the wealth index. We can clearly observe an increase in schooling along the distribution of wealth index.

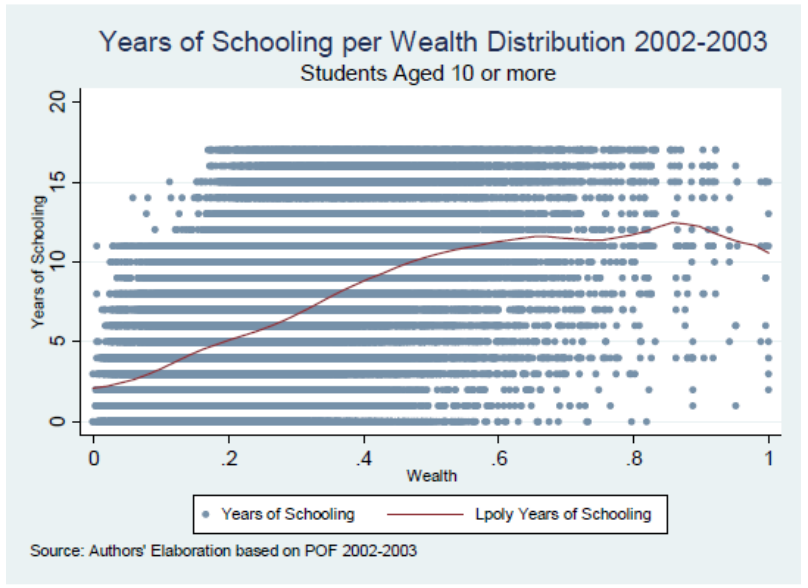

Graph 7: Years of Schoolig per Wealth Distribution 2002-2003

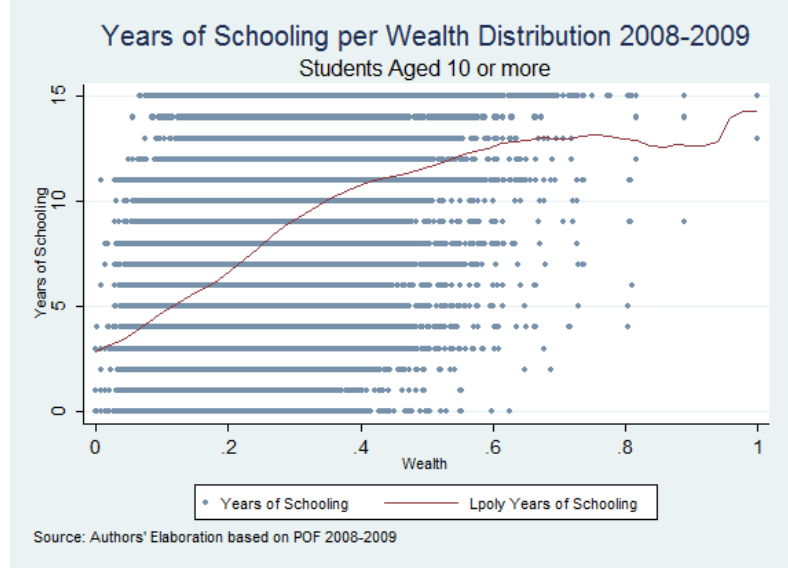

Graph 8: Years of Schooling per Wealth Distribution 2008-2009

To sum up, the descriptive analysis of data points to a positive relation between human capital investment and wealth. Additional graphs of smoothed educational level attainment are presented in the appendix.

Based on the theoretical model presented in section 3, we propose an empirical strategy that relates the level of schooling of each individual with his/her initial wealth. If we find that initial wealth has a significant relationship with school levels, we have evidence that individuals face credit constraint. Our estimates reported on Table 3 and Table 4 refers to the following equation:

$$
e_{i}^{*}=\beta_{0}+\beta_{1} W_{i}+\beta_{2} W_{i}^{2}+\beta_{3} W_{i} * D_{y}+\beta_{4} D_{y}+\beta_{5} D_{S}+\beta_{6} X_{i}+\varepsilon_{i}
$$

where $e^{*}$ is the optimal education decision (educational level attainment per specific ages or years of schooling), $W$ is our measure of initial wealth, $W_{i} * D_{y}$ is a interaction between a dummy variable that controls for time effects and our measure of wealth, $D_{S}$ is a set of dummy variables that captures Brazilian States fixed effects, $X$ is our vector of independent variables, including demographic characteristics of individuals and head of household, besides individual expenditures on education in order to control for educational preferences.

\section{Results}

Table 3 reports the POLS estimates of our empirical model represented by equation (1), for years 2002-2003 and 2008-2009. For all educational level attainment, except for undergraduate and grad- 
uate, we observe a highly significant and positive effect of wealth in level. It is also worth to emphasizing that there is an decrease on credit constraint in the case of preschool, high school level and of education attainment of individuals aged 25 years or more. On the other hand, we also find evidence of an increase of credit constraint between 2002-2003 to 2008-2009 on education decision, specially considering elementary level, undergraduate level and graduate level.

\begin{tabular}{|c|c|c|c|c|c|c|c|}
\hline & (1) & (2) & (3) & (4) & (5) & (6) & (7) \\
\hline VARIABLES & Preschool & $\begin{array}{c}\text { Elementary } \\
\text { Level }\end{array}$ & $\begin{array}{c}\text { High School } \\
\text { Level }\end{array}$ & $\begin{array}{c}\text { Undergraduate } \\
\text { Level }\end{array}$ & $\begin{array}{c}\text { Graduate } \\
\text { Level }\end{array}$ & $\begin{array}{l}\text { Education - } 10 \\
\text { years or more }\end{array}$ & $\begin{array}{l}\text { Education - } 25 \\
\text { years or more }\end{array}$ \\
\hline \multirow[t]{2}{*}{ Wealth } & $0.874^{* * *}$ & $0.978^{* * *}$ & $2.273^{* * *}$ & $-0.496 * * *$ & $-0.440 * * *$ & $10.396 * * *$ & $10.200^{* * *}$ \\
\hline & $(0.201)$ & $(0.150)$ & $(0.127)$ & $(0.094)$ & $(0.077)$ & $(0.408)$ & $(0.414)$ \\
\hline \multirow[t]{2}{*}{ Squared Wealth } & $-0.738^{* *}$ & $-1.438^{* * *}$ & $-2.361 * * *$ & $0.828^{* * *}$ & $0.647^{* * *}$ & $-10.486 * * *$ & $-8.805^{* * *}$ \\
\hline & $(0.287)$ & $(0.211)$ & $(0.166)$ & $(0.129)$ & $(0.101)$ & $(0.614)$ & $(0.595)$ \\
\hline \multirow[t]{2}{*}{ Wealth*Year 2008} & $-0.218^{*}$ & $0.575^{* * *}$ & $-0.346 * * *$ & $0.297 * * *$ & $0.099 * *$ & -0.308 & $-0.750^{* * *}$ \\
\hline & $(0.116)$ & (0.091) & $(0.070)$ & $(0.046)$ & (0.040) & $(0.210)$ & $(0.215)$ \\
\hline \multirow[t]{2}{*}{ Woman } & -0.001 & $0.057^{* * *}$ & $0.068^{* * *}$ & $0.013^{* * *}$ & 0.002 & $0.217^{* * *}$ & $0.042^{* *}$ \\
\hline & $(0.010)$ & $(0.008)$ & $(0.006)$ & $(0.003)$ & $(0.002)$ & $(0.018)$ & $(0.021)$ \\
\hline \multirow[t]{2}{*}{ Black } & -0.003 & $-0.034 * *$ & $-0.045^{* * *}$ & $-0.024^{* * *}$ & $-0.008 * * *$ & $-0.226 * * *$ & $-0.152^{* * *}$ \\
\hline & $(0.023)$ & $(0.016)$ & $(0.013)$ & $(0.005)$ & $(0.003)$ & $(0.036)$ & $(0.040)$ \\
\hline \multirow[t]{2}{*}{ Yellow } & 0.027 & -0.053 & -0.011 & $0.093^{* * *}$ & $-0.037^{* * *}$ & 0.242 & 0.144 \\
\hline & $(0.117)$ & $(0.077)$ & $(0.054)$ & $(0.034)$ & $(0.011)$ & $(0.159)$ & $(0.171)$ \\
\hline \multirow[t]{2}{*}{ Brown } & -0.008 & $-0.029 * * *$ & $-0.038^{* * *}$ & $-0.025 * * *$ & $-0.005^{* *}$ & $-0.231^{* * *}$ & $-0.181^{* * *}$ \\
\hline & $(0.011)$ & $(0.009)$ & $(0.007)$ & $(0.003)$ & $(0.002)$ & $(0.020)$ & $(0.022)$ \\
\hline \multirow[t]{2}{*}{ Indigenous } & 0.072 & 0.075 & $-0.114^{* *}$ & -0.021 & 0.043 & $-0.287^{* *}$ & -0.091 \\
\hline & $(0.065)$ & $(0.063)$ & $(0.051)$ & $(0.016)$ & $(0.039)$ & $(0.123)$ & $(0.140)$ \\
\hline \multirow[t]{2}{*}{ Household Income (in log) } & 0.010 & 0.008 & $0.036^{* * *}$ & $0.017^{* * *}$ & $0.018^{* * *}$ & $0.314^{* * *}$ & $0.283^{* * *}$ \\
\hline & $(0.009)$ & $(0.007)$ & $(0.006)$ & $(0.004)$ & $(0.002)$ & $(0.017)$ & $(0.018)$ \\
\hline \multirow[t]{2}{*}{ Education Expeditures } & $0.032^{*}$ & 0.009 & $0.033^{*}$ & -0.003 & 0.006 & $0.097^{* * *}$ & $0.143^{* * *}$ \\
\hline & $(0.019)$ & $(0.015)$ & $(0.017)$ & $(0.010)$ & $(0.005)$ & $(0.031)$ & $(0.033)$ \\
\hline \multirow[t]{2}{*}{ Total Expeditures } & -0.025 & -0.007 & -0.016 & 0.017 & -0.005 & 0.029 & -0.046 \\
\hline & $(0.020)$ & $(0.016)$ & $(0.018)$ & $(0.011)$ & $(0.005)$ & $(0.032)$ & $(0.035)$ \\
\hline \multirow[t]{2}{*}{ Age } & $0.697^{* * *}$ & $1.785^{* * *}$ & $0.586^{* * *}$ & $0.005^{* * *}$ & $0.002 * * *$ & $0.157^{* * *}$ & $-0.136 * * *$ \\
\hline & $(0.054)$ & $(0.074)$ & $(0.022)$ & $(0.000)$ & $(0.000)$ & $(0.002)$ & $(0.004)$ \\
\hline \multirow[t]{2}{*}{$\mathrm{Age}^{2}$} & $-0.053^{* * *}$ & $-0.055^{* * *}$ & $-0.013 * * *$ & $-0.000^{* * *}$ & $-0.000^{* * *}$ & $-0.003 * * *$ & $0.000^{* * *}$ \\
\hline & $(0.005)$ & $(0.002)$ & $(0.001)$ & $(0.000)$ & $(0.000)$ & $(0.000)$ & $(0.000)$ \\
\hline \multirow[t]{2}{*}{ Household Head Age } & -0.000 & 0.000 & $0.003^{* * *}$ & $0.002 * * *$ & 0.000 & $0.049 * * *$ & $0.077^{* * *}$ \\
\hline & $(0.000)$ & $(0.000)$ & $(0.000)$ & $(0.000)$ & $(0.000)$ & $(0.001)$ & $(0.001)$ \\
\hline \multirow[t]{2}{*}{ Household Head Schoooling } & $0.005^{* * *}$ & $0.006^{* * *}$ & $0.020^{* * *}$ & $0.020^{* * *}$ & $0.006 * * *$ & $0.508^{* * *}$ & $0.681^{* * *}$ \\
\hline & $(0.002)$ & $(0.001)$ & $(0.001)$ & $(0.001)$ & $(0.000)$ & $(0.003)$ & $(0.003)$ \\
\hline \multirow[t]{2}{*}{ Woman Household Head } & 0.014 & -0.009 & -0.006 & $0.006^{*}$ & $0.006 * *$ & $0.198 * * *$ & $0.156^{* * *}$ \\
\hline & $(0.012)$ & $(0.009)$ & $(0.007)$ & $(0.004)$ & $(0.003)$ & $(0.022)$ & $(0.026)$ \\
\hline \multirow[t]{2}{*}{ Preschool Expeditures } & -0.003 & & & & & & \\
\hline & $(0.004)$ & & & & & & \\
\hline \multirow[t]{2}{*}{ Elementary Expeditures } & & -0.002 & & & & & \\
\hline & & $(0.004)$ & & & & & \\
\hline \multirow[t]{2}{*}{ High School Expeditures } & & & $0.005^{*}$ & & & & \\
\hline & & & $(0.003)$ & & & & \\
\hline Undergraduate Expeditures & & & & $-0.008^{* * *}$ & & & \\
\hline & & & & $(0.001)$ & & & \\
\hline Gradute Expeditures & & & & & $0.004 * * *$ & & \\
\hline & & & & & $(0.001)$ & & \\
\hline Brazilian States dummies & $\operatorname{sim}$ & $\operatorname{sim}$ & $\operatorname{sim}$ & $\operatorname{sim}$ & $\operatorname{sim}$ & $\operatorname{sim}$ & $\operatorname{sim}$ \\
\hline Year dummy & sim & $\operatorname{sim}$ & $\operatorname{sim}$ & $\operatorname{sim}$ & $\operatorname{sim}$ & $\operatorname{sim}$ & $\operatorname{sim}$ \\
\hline Constant & $-2.109^{* * *}$ & $-14.492^{* * *}$ & $-7.170^{* * *}$ & $-0.411^{* * *}$ & $-0.158 * * *$ & $-5.858 * * *$ & $-0.723^{* * *}$ \\
\hline & $(0.149)$ & $(0.587)$ & $(0.226)$ & $(0.025)$ & $(0.019)$ & $(0.115)$ & $(0.143)$ \\
\hline Observations & 23,851 & 30,187 & 52,280 & 91,739 & 65,545 & 294,920 & 190,132 \\
\hline$R$-squared & 0.096 & 0.183 & 0.240 & 0.206 & 0.085 & 0.553 & 0.716 \\
\hline Standard errors in parenthes & & & & & & & \\
\hline${ }^{* * *} p<0.01, * * p<0.05, * p<0.1$ & & & & & & & \\
\hline Source: Authors' Elaboration & & & & & & & \\
\hline
\end{tabular}

Table 3: POLS Estimates of Wealth Effects

In other to better understand the results and evaluate the existence of credit constraint, table 4 shows the average marginal effects of wealth and their significance. All estimates are made at the mean value of wealth. The analysis of data reported on Table 4 points to a strong credit constraint before undergraduate level. For example, an increase of one unit of wealth will increase the probability of a child to have preschool on 0.544. Moreover, the effect of credit constraint of education attainment of individuals aged 25 or more corresponds to 5.8 years of schooling. 


\begin{tabular}{|c|c|c|c|c|c|c|}
\hline & \multirow{2}{*}{\multicolumn{2}{|c|}{$\begin{array}{c}\text { Average } \\
\text { Marginal effects }\end{array}$}} & \multirow{3}{*}{$\begin{array}{l}P>|t| \\
0.000\end{array}$} & \multicolumn{2}{|c|}{ [95\% Conf. Interval] } & \multirow{3}{*}{\begin{tabular}{|c} 
Mean Wealth \\
0.224
\end{tabular}} \\
\hline & & & & & & \\
\hline \multirow[t]{2}{*}{ Preschool } & 0.544 & $* * *$ & & 0.327 & 0.761 & \\
\hline & $(0.111)$ & & & & & \\
\hline \multirow[t]{2}{*}{ Elementary Level } & 0.268 & $* * *$ & 0.000 & 0.124 & 0.411 & 0.247 \\
\hline & $(0.073)$ & & & & & \\
\hline \multirow[t]{2}{*}{ High School Level } & 1.095 & $* * *$ & 0.000 & 0.967 & 1.223 & 0.250 \\
\hline & $(0.065)$ & & & & & \\
\hline \multirow[t]{2}{*}{ Undergraduate Level } & -0.042 & & 0.257 & -0.116 & 0.031 & 0.274 \\
\hline & $(0.037)$ & & & & & \\
\hline \multirow[t]{2}{*}{ Graduate Level } & -0.079 & ** & 0.015 & -0.144 & -0.015 & 0.278 \\
\hline & $(0.033)$ & & & & & \\
\hline \multirow[t]{2}{*}{ Education - 10 years or more } & 5.203 & $* * *$ & 0.000 & 4.836 & 5.571 & 0.248 \\
\hline & $(0.188)$ & & & & & \\
\hline \multirow[t]{2}{*}{ Education - 25 years or more } & 5.771 & $* * *$ & 0.000 & 5.372 & 6.169 & 0.252 \\
\hline & $(0.203)$ & & & & & \\
\hline \multicolumn{7}{|l|}{$* * * p<0.01, * * p<0.05, * p<0.1$} \\
\hline \multicolumn{2}{|l|}{ Source: Authors' Elaboration } & & & & & \\
\hline
\end{tabular}

Table 4: Average Marginal Effects of Wealth on Human Capital Investment

It is worth mentioning that the absence of credit constraint on high level education decisions can be related to the high quality of several public universities in Brazil as well as to the recent education policies focused on the access of needy students to public and private undergraduate schools or graduate courses.

\section{Conclusion}

In this paper we explore the effect of wealth index on education level attainment and years of schooling in order to investigate if individuals in Brazil face credit constraint on education decision. Following the theoretical model of Lochner \& Monge-Naranjo (2011), we propose an empirical strategy based on a reduced form estimate of the relation between wealth index and optimal education decisions.

Our results point that human capital investment decision is in fact constrained by the wealth. On average, the wealth was responsible for an increase of more that 5 years of schooling. It is also important to note that we did not find evidence of credit constraint concerning the undergradute and graduate levels.

Further steps of this study includes the development of an structural empirical model, that will help us to better identify a causal relationship between wealth and human capital investment decisions.

The findings of this study are very important to shed some light on the efficiency and scope of recent Brazilian policies that focus on educational financial aid, like FIES (Student Financing Fund -"Fundo de Financiamento Estudantil") PROUNI (University for All Program "Programa Universidade para Todos"), and on the increase in the number of students in the Federal Universities.

\section{References}

[1] Acemoglu, Daron; Johnson, Simon e Robinson, James. Reversal of fortune: geography and institution in the making of the modern world income distribution. Quarterly Journal of Economics. Vol. 117 (November), pp. 1231-1294. 2002

[2] Aghion, P. e Bolton, P. A theory of trickle-down growth and development. The Review of Economics Studies, v.64, p. 151-172, 1997.

[3] Aghion, P, Caroll, E. e Garcia-Peñalosa, C. Inequality and economic growth: the perpective of the new growth theories. NBER working paper, n.9908, 1999.

[4] Almeida, R. A. P., Bianchini Z. M. Aspectos de amostragem da pesquisa de economia informal urbana 97. Rio de Janeiro: IBGE Texto para discussão, n.89, 1998. 
[5] Andersen, L. E.; Nina, O. Micro-Credit and group lending: the collateral effect. In: Latin American and Caribbean Economic Association, V Annual Meeting, 2000, Rio de Janeiro. Anais eletrônicos. Rio de Janeiro: LACEA, 2000. Disponível em CD-ROOM.

[6] Assunção, J ; Chein, Flávia. Condições de Crédito no Brasil Rural. Revista Economia e Sociologia Rural, v. 42(2), p. 367-407, 2007.

[7] Assunção, J ; Alves, Luciana. Restrições de Crédito e Decisões Intra-familiares. Revista Brasileira de Economia, v. 61(2), p. 201.229, 2007

[8] Banerjee, A. V. e Newman, A. F. Risk-bearing and the theory of income distribution. The Review of Economics Studies, v.58, p. 211-235, 1991.

[9] Banerjee, A. V. e Newman, A. F. Occupational choice and the process of development. Journal of Political Economy, v.101, p. 274-298, 1993.

[10] Blundel, Richard e Dias, Monica Costa. Alternative approaches to evaluation in empirical microeconomics. The Institute for Fiscal Studies, Department of Economics. Cemmap Working Paper, 10/02. 2002.

[11] Braverman, A. e Stiglitz, E. J. Sharecroping and the interlinking of agrarian markets. The American Economic Review, v.72(4), p. 695-715, 1982.

[12] Braverman, A. e Snirivasan, T. Agrarian reforms in developing rural economics characterized by interlinked credit in tenancy markets. In:. Contractual arrangements, employment, and wages in rural labor markets in Asia. New York: Yale University Press, 1984, p. 32-78.

[13] Bell, C. Credit markets and interlinked transactions. Handbook of Development Economics, v.1, p. $761-830,1988$.

[14] Bell, C. e Snirivasan, T. Some aspects of linked product and credit market contract among riskneutral agents In: The economic theory of agrarian instituions. New York: Clarendon Press, 1989, p. 113-155.

[15] Bell, C. Srivasan, T. e Udry, C. Rationing, spillover, and interlinking in Credit Markets: the case of Rural Punjab. Oxford Economic Paper, v.49, p. 557-585, 1997.

[16] Besley, T.; Burgess. Land Reform, Poverty Reduction and Growth: Evidence from India, The Development Economics Discussion Paper Series. 1998

[17] Bourguignon, F. e Ferreira F. H. G. Understanding inequality in Brazil: a conceptual overview". Rio de Janeiro: Departamento de Economia - PUC-Rio. Texto para discussão, n.434, 2000.

[18] Carneiro, P e Heckman, J. The evidence on credit constraints on post-secondary school. The Economic Journal, v.112, p.705-734, 2002.

[19] Cameron, S e Taber, C. Estimation of educational borrowing constraints using returns to Schooling. Journal of Political Economy, v.112, 2004.

[20] Deininger, K. Making negotiated land reform work: initial experience from Colombia, Brazil, and South Africa. Policy Research Working Paper Series, n. 2040. World Bank: Janeiro, 1999.

[21] Diagne, A. Determinants of household access to and participation in formal and informal credit markets in Malawi. FCD Dicussion Paper, n.67, 1999. 
[22] Evans, David S. e Jovanovic, Boyan . An Estimated Model of Entrepreneurial Choice under Liquidity Constraints. Journal of Political Economy, Volume 97, No. 4, p. 808-827, 1989.

[23] Galor, O. e Zeira, J. Income distribution and macroeconomics. The Review of Economics Studies, v.60, p. 35-52, 1993.

[24] Gallup, J.L. et al. Geography and economic development. International Regional Science Review, 22, 2. August 1999.

[25] Galor, Oded; Zeira, Joseph. Income Distribution and Macroeconomics, Review of Economic Studies 66. 1993

[26] Gangopadhyay, S. e Sengupta, K. Interlinkages in rural markets. Oxford Economic Papers, v.38, p. 112-121, 1986.

[27] Ghatak, M \& Jiang, N. A simple model of inequality, occupational choice, and development. Journal of Development Economics, 69. 2002

[28] Hoff, K. e Stiglitz, E. J. Imperfect information and rural credit markets: puzzles and policy perpectives. In: The economics of rural organization: theory, practice and policy. New York: Oxford Press, 1993.

[29] IBGE (Instituto Brasileiro de Geografia e Estatística). Pesquisa de Orçamentos Familiares 20022003. Rio de Janeiro, 2006.

[30] Jaffe, D. M. e Russel T. Imperfect information, uncertainty and credit rationing. The Quartely Journal of Economics, v.90(4), p. 651-666, 1976.

[31] Jacoby , G. H. e Skoufias, E. Risk, financial markets and human capital in a developing country. Review of Economic Studies, v.64, p. 311-335, 1007.

[32] Jehle, G. A. e Reny, P. J. Advanced microeconomic theory. New York: Addison-Wesley-Longman, 2001.

[33] Kochar, A. An empirical investigation of rationing constrain in rural credit markets in India. Journal of Development Economics, v.53, p. 339-371, 1997.

[34] Lipton, M.; Ravallion, M. Poverty and Policy. In: Handbook of Development Economics, 3. Jere Behrman and T. N. Srinivasan, eds. Amsterdam: North-Holland, pp. 2551- 657. 1995

[35] Lochner, Lance; Monge-Naranjo, Alexander. Credit constraints in education. NBER Working Paper, no. 17435. Sept, 2011.

[36] Loury, G. C. Intergerational transfer and the distribution of earnings. Econometrica, 49(4), p. 843-867, 1981.

[37] Mas-Colell, A., Whinston, M. e Green, J. Microeconomic Theory. New York: Oxford University Press, 1995.

[38] Madeira, Gabriel; Rangel, Marcos A.; Rodrigues, Mauro. Judicial risk and borrowing constraints: inferential evidence from changes in avaibility of credit instruments. In: Encontro Brasileiro de Econometria, 32, 2010, Salvador. Avaiable at : $<$ http://bibliotecadigital.fgv.br/ocs/index.php/sbe/EBE10/index $>$.

[39] Mimoun, M. Credit Constraint in Education: Evidence from Internacional Data. Journal of Applied Economics, v. 11, pp. 33-60. 
[40] Piketty, T. The dynamics of the wealth distribution and the interest rate with credit rationing. The Review of Economic Studies, v.64, p. 173-189, 1997.

[41] Ravallion, M.; Sen, B. Impacts on Rural Poverty of Land-Based Targeting: Further Results of Bangladesh, World Development 22 (6): 823-38. 1994

[42] Romer, D. Advanced Macroeconomics. New York: McGraw-Hill, 2001.

[43] Rosenzweig, M. e Wolpin, K. Credit market constraints, consumption smoothing and the accumulation of durable production assets in low income countries: investments is bullocks in India. Journal of Political Economy, v.101, p. 101-135, 1993

[44] Stiglitz, J. E. Distribution of income and wealth among individuals. Econometrica, v.37(3), p. 55-89, 1969.

[45] Stiglitz, J. E. e Blinder A. Money, credit constrains and economic activity. The American Economic Review, v.73(2), p. 296-302, 1983.

[46] Stiglitz, J. E. e Weiss A. Credit rationing in markets with imperfect information. The American Economic Review, v.71(3), p. 393-410, 1981.

[47] Stiglitz, J. E. Peer Monitoring and Credit Markets. In: The economics rural organization: theory, pratice and policy. New York: :Oxford University Press, 1993.

[48] Smith, Jeffrey e Todd, Petra. Does matching overcome Lalonde's critique of noexperimental estimators? PIER Working Paper 01-035. Penn Institute for Economic Research, University of Pennsylvania, November. 2000

[49] Townsend, M. R. Financial markets and poverty-an algorithm for policy based research and research-based policy. Chicago: Economics Department, 2002, mimeografado.

\subsection{Appendix}

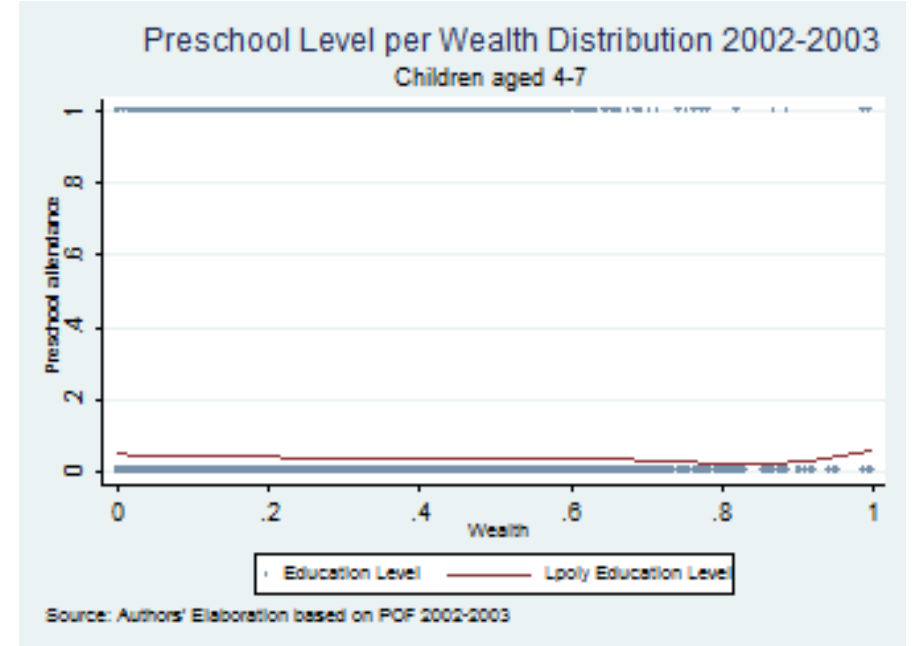

Graph A1: Preschool per Wealth Distribution 2002-2003 


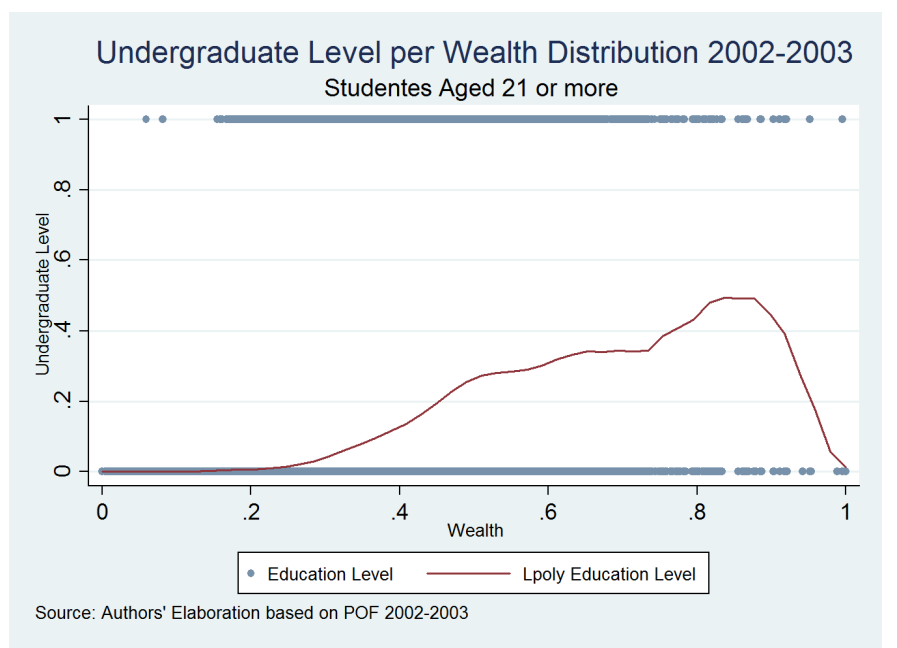

Figure 1: Graph A4: Undergraduate per Wealth Distribution 2002-2003

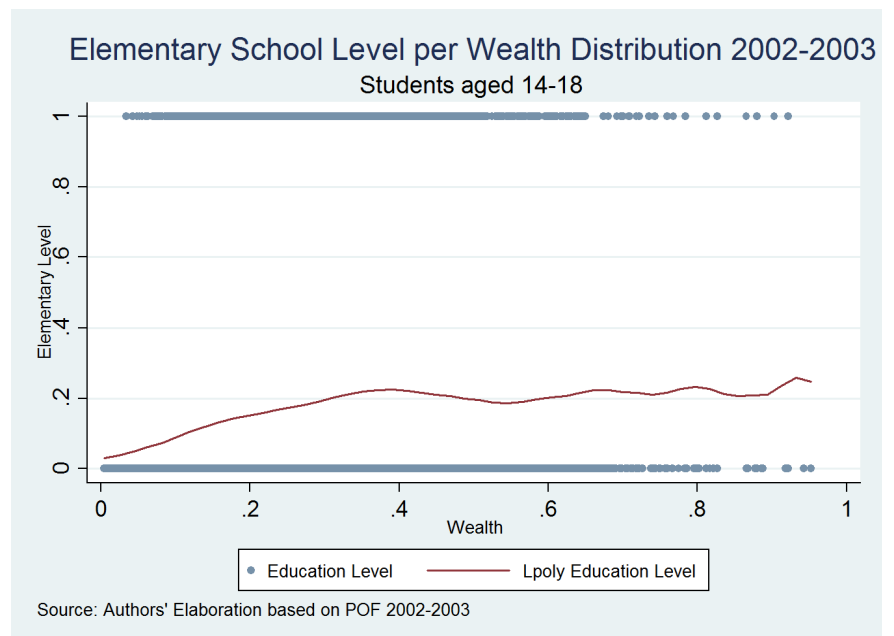

Graph A2: Elementary School per Wealth Distribution 2002-2003

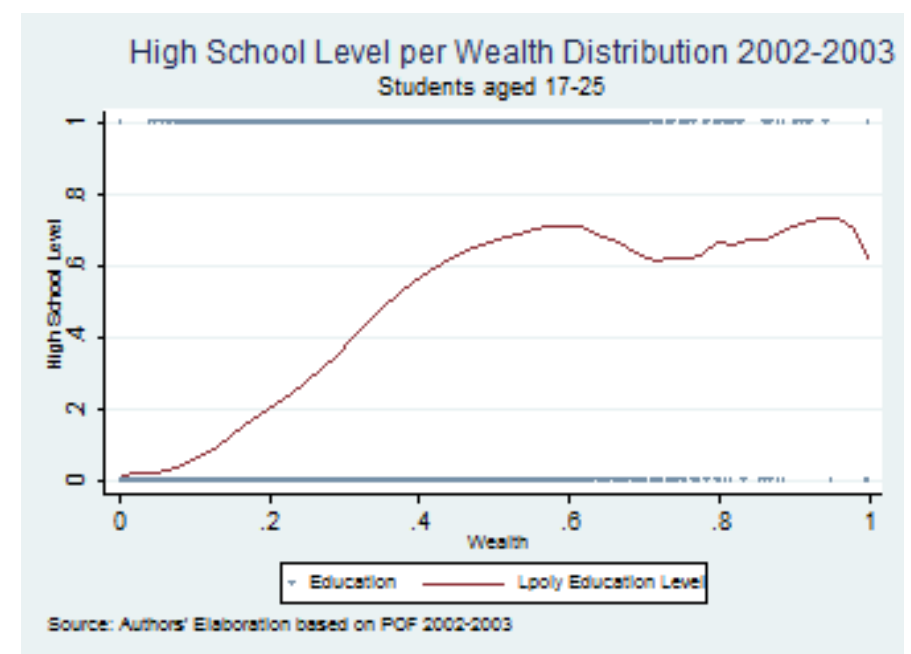

Graph A3: High School per Wealth Distribution 2002-2003 


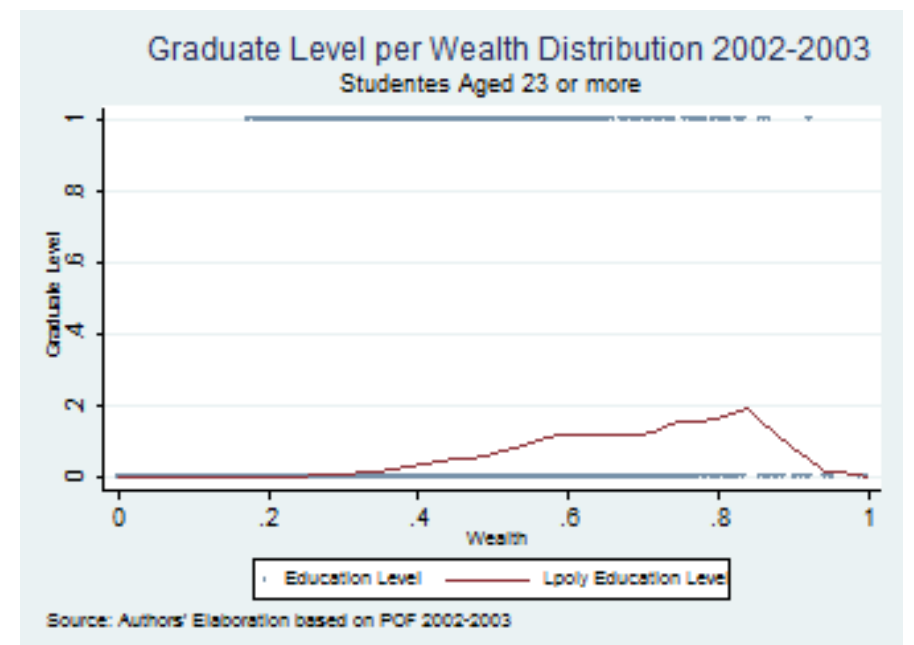

Graph A5: Graduate per Wealth Distribution 2002-2003

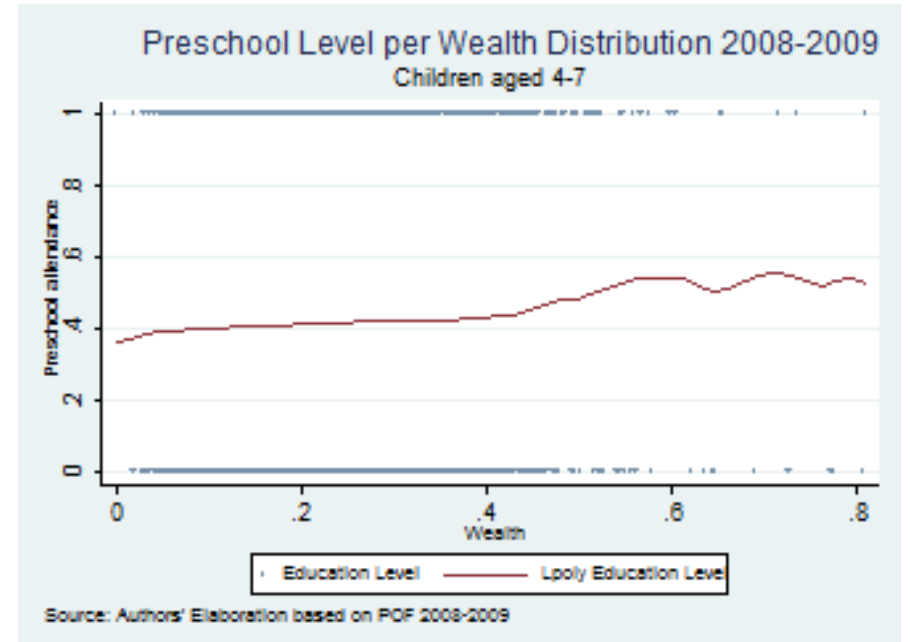

Graph A6: Preschool per Wealth Distribution 2008-2009

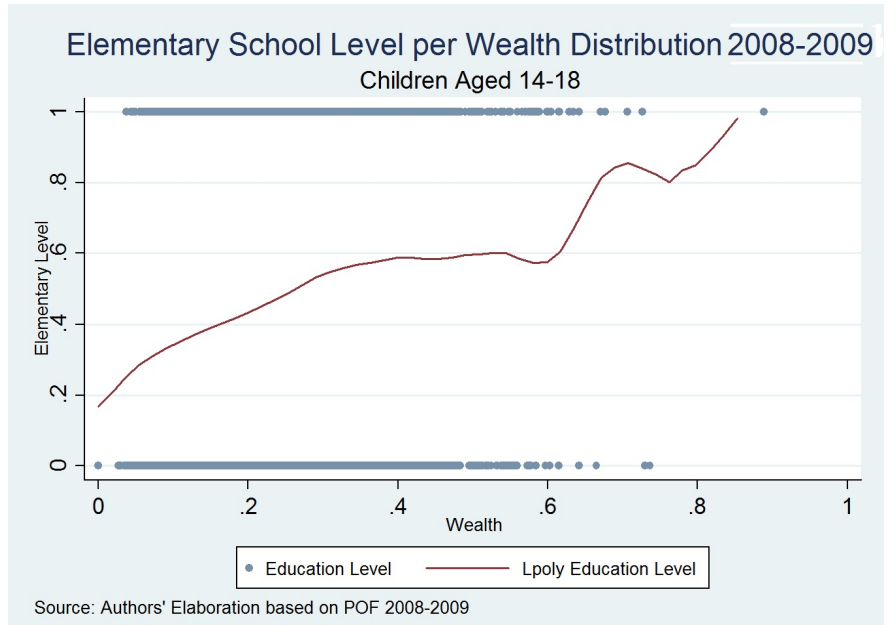

Graph A7: Elementary School per Wealth Distribution 2008-2009 


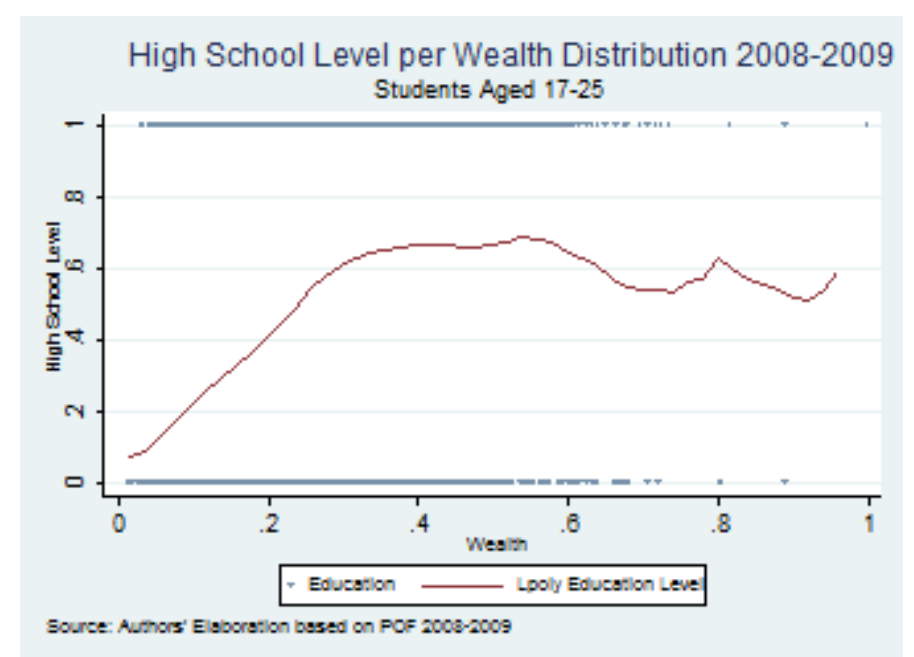

Graph A8: High School per Wealth Distribution 2008-2009

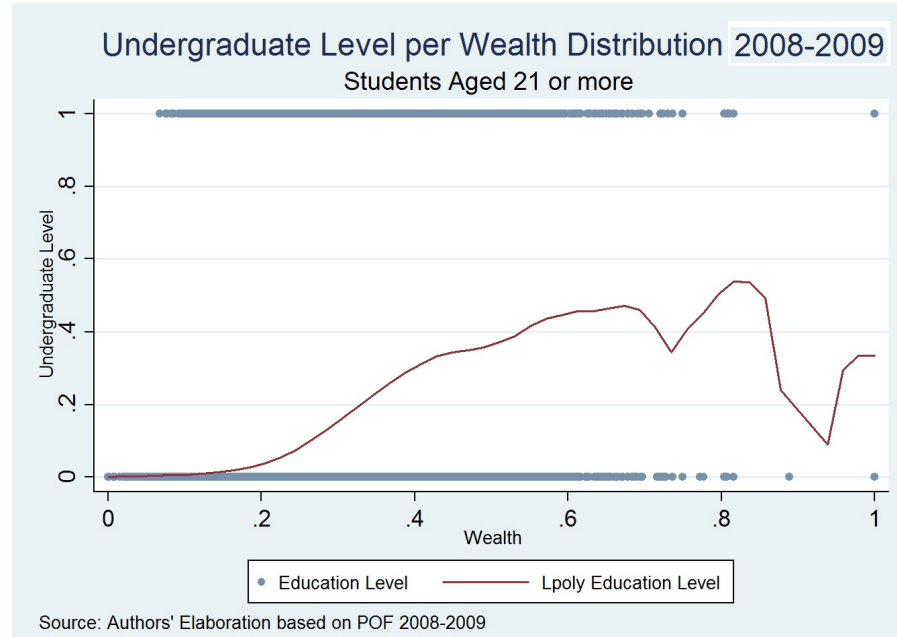

Graph A9: Undergraduate per Wealth Distribution 2008-2009

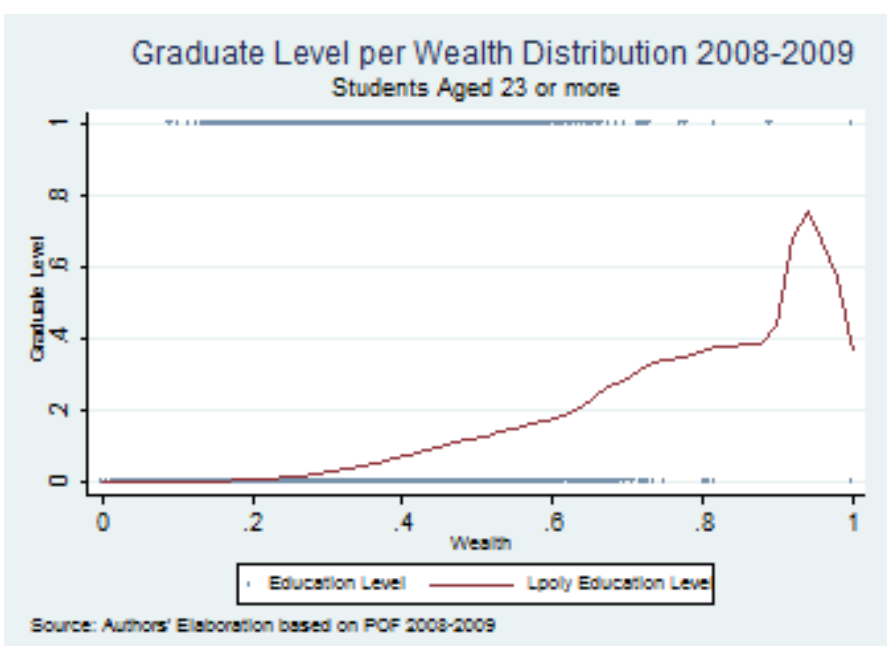

Graph 10: Graduate per Wealth Distribution 2008-2009 